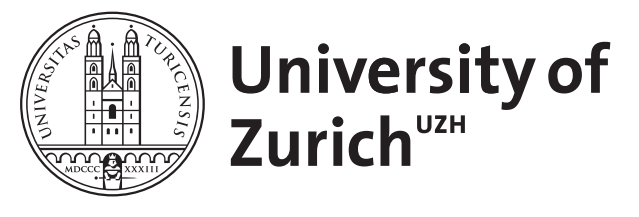

\title{
Mercury as an Antisyphilitic in Ayurvedic Medicine
}

\author{
Wujastyk, Dagmar
}

\begin{abstract}
In the sixteenth century, a new disease appeared in India. Described for the first time in the ayurvedic classic Bhāvaprakāśa by Bhāvamiśra, it was called phiraṅgaroga, "disease of the Franks". Given the name and what we know from contemporary reports of European observers in India, this was very likely the correlate to the so-called "French disease" or "Morbus Gallicus", i.e., syphilis. The Bhāvaprakāśa describes the symptoms and various stages of phirañgaroga and presents seven different cures. Five of these prescribe the use of mercury: Three recipes for the ingestion of mercury, one recipe for using mercury as a fumigant and one in which mercury is rubbed into the patient's hands. In this chapter, I will discuss Bhāvamiśra's representation of the disease and the therapies he proposes for it. I will in particular analyze the use of mercury in the anti-phirangaroga medicines, contextualising them within the history of the use of mercury in ayurvedic medicine and exploring possible links with antisyphilitic therapies in European, Persian, Arabic and Chinese medicine.
\end{abstract}

DOI: https://doi.org/10.1515/asia-2015-1046

Posted at the Zurich Open Repository and Archive, University of Zurich

ZORA URL: https://doi.org/10.5167/uzh-123083

Journal Article

Published Version

Originally published at:

Wujastyk, Dagmar (2015). Mercury as an Antisyphilitic in Ayurvedic Medicine. Asiatische Studien / Études Asiatiques, 69(4):1043-1067.

DOI: https://doi.org/10.1515/asia-2015-1046 


\title{
Dagmar Wujastyk*
}

\section{Mercury as an Antisyphilitic in Ayurvedic Medicine}

DOI 10.1515/asia-2015-1046

\begin{abstract}
In the sixteenth century, a new disease appeared in India. Described for the first time in the ayurvedic classic Bhāvaprakāśa by Bhāvamiśra, it was called phirangaroga, "disease of the Franks". Given the name and what we know from contemporary reports of European observers in India, this was very likely the correlate to the so-called "French disease" or "Morbus Gallicus", i.e., syphilis. The Bhāvaprakāśa describes the symptoms and various stages of phirangaroga and presents seven different cures. Five of these prescribe the use of mercury: Three recipes for the ingestion of mercury, one recipe for using mercury as a fumigant and one in which mercury is rubbed into the patient's hands. In this chapter, I will discuss Bhāvamiśra's representation of the disease and the therapies he proposes for it. I will in particular analyze the use of mercury in the anti-phirangaroga medicines, contextualising them within the history of the use of mercury in ayurvedic medicine and exploring possible links with antisyphilitic therapies in European, Persian, Arabic and Chinese medicine.
\end{abstract}

Keywords: Ayurveda, mercury, calomel, syphilis, Indian medical literature

\section{Phirangaroga: The disease of the others}

In the sixteenth century, a new disease appeared in India. First described in the ayurvedic classic Bhāvaprakāśa by Bhāvamiśra, it was called phirangaroga. ${ }^{1}$ The Sanskrit compound term phirangaroga means the disease (roga) of the "Franks" (phiranga), an umbrella term for Europeans or simply foreigners that could also

1 The Bhāvaprakāśa is one of six Indian medical works that are considered particularly authoritative in the ayurvedic tradition. These works, all written in Sanskrit, are divided into two sets of three: the so-called "great three" (brhhattrayī) or "old three" (vṛddhatrayī) and the "small three" (laghutrayi)). The "great three" are the Carakasaṃhitā, the Suśrutasaṃhitā and the Aș̣āngahậdayasaṃhitā, which were composed some time between the first and the seventh centuries CE, the "small three" are the Mādhavanidāna (eighth century CE), the Saarnngadharasaṃhitā (thirteenth to fourteenth century CE) and the Bhāvaprakāśa (sixteenth century CE).

*Corresponding author: Dagmar Wujastyk, Institute for South Asian, Tibetan and Buddhist Studies, University of Vienna, Spitalgasse 2, 1090 Wien, Austria. E-mail: dagmar.wujastyk@univie.ac.at 
more specifically refer to the Portuguese, to Eurasians or to Luso-Asians. ${ }^{2}$ From at least the nineteenth century, scholars translating the Sanskrit medical works or writing about them have assumed that phirangaroga, the disease of the Franks, was the correlate to the so-called "French disease" or "Morbus Gallicus", i.e., syphilis. ${ }^{3}$ This assumption was based on the name given to the disease, on the description of its symptoms, as well on the fact that European observers such as Ludovico di Varthema and Garcia da Orta thought they were witnessing syphilis in India in the sixteenth century. ${ }^{4}$ The description of this disease in the Bhāvaprakāśa contains the first specific mention of Europeans in Indian medical literature. It is also worth noting that Bhāvamiśra's description of phirangaroga may be the only reference to the disease in all of sixteenth-century Sanskrit literature. Even contemporary medical works (as far as we can identify them as belonging to the sixteenth century) do not mention it. ${ }^{5}$ However, in the seventeenth century, several medical works appeared that refer to phirangaroga, some of them suggesting treatments. Among these are Trimallabhattạ's Yogatarañgin̄i (first half-to mid-seventeenth century), Bindu's Rasapaddhati (possibly first half of seventeenth century), Mevārāmamiśra's Vaidyakaustubha (mid-to late-seventeenth century), Rāvaṇapaṇdita’s Arkaprakāśa, Prāṇanātha’s

2 See Yule/Burnell (2000 [1903]: 352-354) on “Firinghee".

3 By the modern biomedical definition, syphilis is a venereal disease caused by the spirochete bacterium treponema pallidum. Given that microorganisms as causative factors for diseases were not known until the nineteenth century and that treponema pallidum was only identified in 1905, we cannot know whether the disease described by Bhāvamiśra was in fact syphilis as we understand it today, just as the identification of the sets of symptoms described in European publications as "Morbus Gallicus" or "French disease", later named "syphilis" by Girolamo Fracastoro in his play Syphilis sive morbus gallicus (1530), cannot be understood to exactly represent what we understand as syphilis today. Patients suffering from Morbus Gallicus (or phirangaroga) may not have been infected with treponema pallidum, or else they may have, but some of their symptoms, seen as indicative of Morbus Gallicus, may have been due to other factors. The term phirangaroga is found in many later ayurvedic works and seems to be used in the same way Bhāvamiśra employs it and in India today, syphilis is called firangrog in Hindi, pointing to a certain continuity in the identification (if not understanding) of the disease.

4 See, for example, di Varthema 1863: 274 and 156 (though one should note that the Indian name Varthema mentions for the "French disease" is "pua" and not phirangaroga) and Garcia da Orta, who describes treating patients for syphilis in his Colloquies (da Orta1987 [1913]: 379). 5 The Basavaräjiya may be the exception to this rule, if we understand its description of mehavraṇa (Basavarājīya, chapter 9, Basavarāja 2005: 168) to correspond to Bhāvamiśra's blister of external phiranga. Reddy (1936: 29) notes that the Indian chroniclers and biographers do not seem to have recorded anything on the subject and that Telegu literature of the Vijayanagara Court has not yielded any positive evidence. A thorough search of the vernacular literatures and records in Malayalam and Kanarese might, however, bring up more relevant data. 
Rasapradipa, and the Dhanvantari (an anonymous work, probably later than the Bhāvaprakāsa). ${ }^{6}$ Further works might be added to this list: many Sanskrit medical works cannot be authoritatively dated.

\section{The disease}

The Bhāvaprakāśa devotes a short chapter in its therapy section to phirañgaroga and its treatments. ${ }^{7}$ The chapter begins with an explanation for the name of the disease, namely that it refers to the disease's country of origin, "phirangadeśa", the country of the Franks (and given the broad understanding of the term phiranga this could mean Europe, Portugal, or indeed those parts of India inhabited by the Portuguese, e.g. Goa and parts of the Malabar coast), as well as to the idea that the disease is contracted through contact with Franks and from sexual intercourse with their women (phiranginini). The author Bhāvamiśra categorizes the disease as "āgantu", which may be translated as "exogenous" or perhaps as "invasive", since the disease entity enters into the body from outside. This is one of the classic disease categorizations already found in the oldest of the Sanskrit medical texts available to us, the Carakasamphitā (c. first century $\mathrm{CE}$ ), which states that there are three kinds of disease: the internally caused (nija), the invasive (āgantu), and the mental (mānasa). Internal diseases arise out of the body's humours, mental disease is brought about through certain mental processes, while invasive diseases arise from outside influences such as poisons, fire or wounding. ${ }^{8}$ Outside influence may also encompass contagion,

6 The Yogataranginī only mentions phiranga, but does not discuss it as a separate disease category. See Meulenbeld 1999-2002: IIA, 318. For references to phirangaroga in Bindu's Rasapaddhati, Mevārāmamiśra’s Vaidyakaustubha, Rāvaṇapaṇdita’s Arkaprakāśa, Prāṇanātha’s Rasapradipa, and the anonymous Dhanvantari, see Meulenbeld 1999-2002, IIA, 644, 305, 468, 763 , and 507, respectively.

7 The Bhāvaprakāśa is divided into three large sections, the pūrvakhaṇda, the madhyakhaṇda and the uttarakhanda. The chapter on phirangaroga is located in the madhyakhanda (the middle section). It is the 59th of 71 chapters that describe particular diseases or disease categories and the appropriate therapies (Sanskrit: cikitsā) against them. Phiranga is is part of a section dedicated to skin diseases (or diseases that manifest on the skin) and is placed between chapters on visphoța ( small pox) and masūrika ( chicken pox). The edition of the Bhāvaprakāśa by Srikantha Murthy (1998-2000) was used for this article.

8 Carakasaṃhitā Sūtrasthāna 11.45. See Dominik Wujastyk 2003: 31. The Carakasaṃhitā edition by Sharma (2003) was used for this article. The doctrine of the three humours wind (vāta), bile (pitta) and phlegm (kapha) is one of the key concepts in ayurvedic medicine, though the classical texts display some disparity in their definition of how the humours function. In the 
i.e., disease caused by contact with persons afflicted with disease, and is particularly associated with skin disease, fever, consumption and eye diseases. This notion generally plays a minor role in ayurvedic nosology, but is already discussed in the Suśrutasaṃhitā (c. third century CE). ${ }^{9}$ Bhāvamiśra explains that since the disease entity comes from outside the person, complications of the humours are a secondary development, and must be recognized through their symptoms. He classifies three kinds, or perhaps three stages of phirangaroga: External (bāhya), internal (abhyantara) and both external and internal (bahirantarbhāva). External phirangaroga manifests "like visphoța". Visphoța can refer to a whole disease category of vesicular disease, but in this instance probably simply means a boil or a blister. ${ }^{10}$ Bhāvamiśra explains that the boil is treated like an ulcer (vrana) once it has burst, that is, presumably with a dietary

seminal seventh-century treatise Aștāngahṛdayasaminhiā, they are defined as both necessary substances in the body that fundamentally sustain its functioning and as potential sources for the arising of disease. Disease may arise when there is an imbalance in the proportional quantity of the humours, i.e., a pathological predominance of one or two of the humours or conversely their pathological diminution; if one or several of the humours spread outside their normal pathways; or if one or several of them are hindered from flowing through their normal pathways. Mitigating a humour means to counteract its abnormal growth and thus avoiding its overflow from the area that is supposed to contain it, or to counteract its diminution and its decreased flow and functioning in the body. See Așțāngahṛdayasaṃhitā Sūtrasthāna 11. The edition by Srikantha Murthy (1991-1995) was used for all passages of the Aștāñgahṛdayasaṃhitā.

9 See Suśrutasaṃhitā Nidānasthāna 5.33-34: "Skin disease, fever, consumption, oozing of the eyes, and diseases resulting from contact with a diseased person (upasarga) pass from person to person because of [the following]: sexual intercourse [with a diseased person], touching [a diseased person's] body, breathing [near a diseased person], eating from a [diseased person's vessel], sharing [a diseased person's] bed or seat, or using a [diseased person's] clothes, flowery garlands, or unguents.” (Zysk 2000: 88). The Suśrutasaṃhitā edition by Sharma (1999-2001) was consulted for this article.

10 In older works, visphoța is a subcategory of kuștha (skin diseases and leprosy). See Jolly (1994 [1951]: 122 and 118) on visphoța, and visphoța as a subcategory of kușța, respectively. In the context of kuștha, visphoța describes "dark red swellings with thinner skin” (Jolly 1994 [1951]: 118). In the Bhāvaprakāśa's chapter on visphoța, it is described as being caused by aggravated humours that vitiate the blood, flesh and bones and then localise in the skin, giving rise to vesicles that may appear either in one part of the body on on the entire body. Depending on which humour is predominantly aggravated, the appearance of the vesicles and the accompanying symptoms differ. Bhāvamiśra counts eight different types of visphoța. Only one of these, the third category of visphoța, which is caused by the aggravated humour "phlegm" (kapha), causes no pain, which is the initial characteristic of external phiranga mentioned by Bhāvamiśra. However, a patient suffering from kapha-born visphoța would also experience vomiting, loss of taste and exhaustion, and the vesicles would itch. Since Bhāvamiśra makes note of painlessness, but not of itching or other symptoms, it seems to me that visphota in the 
regimen, a prescription of several herbal decoctions and the application of herbal pastes and poultices to the affected skin. ${ }^{11}$ Bhāvamiśra considers this condition easy to cure. Internal phiranga is likened to a disease called âmavāta. Its symptoms are pain and swelling in the joints and it is considered difficult to cure. ${ }^{12}$

Bhāvamiśra next describes the complications, or late stages (upadrava) of phiranga: emaciation, loss of strength, decay of the nose, sluggish digestion, bone atrophy and bone curvature. He concludes his description of the disease by repeating that external phiranga is easy to cure if its onset is recent and if there are no complications and that internal phiranga is difficult to cure. However, the disease can no longer be cured if the patient is weakened from chronic internal and external phiranga, if he suffers from the above-mentioned complications, and if the disease has spread. This, Bhāvamiśra notes, is what the ancient sages say on the subject - an interesting statement, given that the Bhāvaprakāśa is the first of the ayurvedic works to mention the disease.

\section{The treatments}

Bhāvamiśra presents us with seven different cures for phirangaroga. Five of these prescribe the use of mercury: three recipes for the ingestion of mercury, one recipe using mercury as a fumigant and one in which the patient rubs mercury into his hands. The predominance of mercury is unusual for the Bhāvaprakāsa. Out of 71 chapters in the therapy section, only fifteen prescribe mercury, usually placing one recipe for a medicine containing mercury or cinnabar at the end of a list of several herbal medicines. The chapter on phirañgaroga breaks Bhāvamiśra's general pattern, since mercurial medicines are given pride of place and also outnumber the non-mercurial remedies in it.

instance of external phiraiga simply means a boil, or a blister, or perhaps even a broad rash with many vesicles, but probably not the specific disease category of visphota.

11 On the classification and treatment of ulcers in ayurvedic medicine, see Jolly 1994 [1951]: 132-133.

12 Compare these symptoms with those that Bhāvamiśra lists for āmavāta: Pain all over the body, loss of taste, thirst, lassitude, feeling of heaviness in the body, fever, non-digestion of food, swelling of the limbs. The symptoms of advanced àmavāta include swelling and extreme pain in the joints (the pain is compared to the pain of scorpion bites), excessive salivation, having a bad taste in the mouth and polyuria. Complications include hardness of the abdomen, colics, insomnia, vomiting, dizziness, pain in the heart, constipation, and flatulence. 
Bhāvamiśra's main (or at least first) recipe for treating phirañgaroga describes the ingestion of rasakarpüra ("mercury that is like camphor", i.e., a white powder). This was either mercurous chloride (calomel) or mercuric chloride (corrosive sublimate), or a mixture of both. ${ }^{13}$ Bhāvamiśra tells us that rasakarpūra was pronounced effective against phiraniga by the physicians of old. In his first recipe, he describes how about $500 \mathrm{mg}$ of rasakarpüra are encased in wheat flour. The resulting pill is then covered in ground cloves and is swallowed whole with some water. Afterwards, the patient may chew some betel leaves, but should avoid salty and sour foods, as well as greens. Patients are further advised not to exert themselves, to avoid exposure to heat and travel, and most of all, to refrain from sexual intercourse with women. The advice to abstain from salt is given for all treatments with mercury, while the avoidance of sour foods is advised in three of the mercurial therapies. The second recipe describes the making of saptaśálivațika (seven grain-of-rice pills). Here, mercury is mixed with catechu (khadira), pellitory root (ākārakarabha) and honey, and the patient takes a pill a day for seven days. ${ }^{14}$

The third mercurial cure for ingestion is quite complicated and involves making a paste of mercury, sulphur and catechu to which a number of herbs, namely Indian rose chestnut (also called cobra's saffron, or Ceylon ironwood), cardamom, cumin and caraway, bishop's weed, sandal, long pepper, bamboo, ${ }^{15}$ spikenard and bastard cinnamon, honey and ghee are added. The powder of this

13 The processing of mercury is described at some length in chapter seven of the Bhāvaprakāśa's pūrvakhanda (dhātvādiśodhanamāranavidhiprakaranam 146-199). The preparation of rasakarpūra is described in verses 182-190. Uday Chand Dutt called rasakarpūra "perchloride of mercury" or "corrosive sublimate", though he noted that the product available at medical markets at the time of his writing (in the 1870s) was not pure perchloride of mercury, but a mixture of calomel and corrosive sublimate. See Dutt 1877: 37. Dole/Paranjpe (2004: 141144) define rasakarpūra as corrosive sublimate $\left(\mathrm{HgCl}_{2}\right)$, but explain that some recipes for rasakarpūra produce a mixture of corrosive sublimate and calomel, the latter's proper Sanskrit name being rasapuspa.

14 It should be noted that plant nomenclature and identification in Ayurveda is a difficult subject. There are some plant materials whose identity is fairly certain. However, in other cases, identification, while not entirely guesswork, is more tentative. See Dominik Wujastyk 2003:

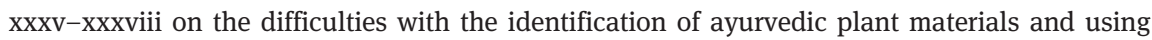
international Latin taxonomies (which are also not always consistent). I have tried to use English vernacular names as far as possible for this chapter, orientating myself on entries in the Kew Royal Botanical Gardens Medicinal Plant Names Services (http://www.kew.org/scienceconservation/research-data/resources/medicinal-plant-names-services) both for English and Latin names of plant names given in Sanskrit in the ayurvedic source texts.

15 Sanskrit: vamsalocana. Rather than the stem or shoot of the plant, this refers to a translucent white substance found the nodal joints of some species of bamboo, composed mainly of silica and water with traces of lime and potash. 
concoction is used against ulcers. Bhāvamiśra also notes that there will be no swelling in the mouth with this medicine.

In the fourth mercurial cure, mercury is mixed with sulphur and rice and the mixture is formed into seven pills. These are used for fumigation, one a day for seven days. Bhāvamiśra does not specify whether the vapours of the pills are to be inhaled or whether the affected parts of the body are to be fumigated. The latter is a standard ayurvedic procedure in skin diseases. ${ }^{16}$ However, the text says "one should apply smoke" (dhūmam prayojayet), which implies the inhalation of smoke, as the Sanskrit technical term for the fumigation of the body is dhūpana. $^{17}$

The last mercurial recipe prescribes rubbing mercury and the juice of the leaves of yellow-flowering country mallow (pitapușpabalā) into one's hands until they are absorbed by the skin. ${ }^{18}$ The hands are then heated and made to sweat.

Two further cures involve the use of herbal substances, one being composed of plant materials standardly used in ayurvedic formulations (neem leaves, the emblic and chebulic myrobalans, and turmeric), the other consisting of a foreign plant: cobacini, or China wood (more commonly known as China root), the powder of which is to be taken with honey. Bhāvamiśra advises to avoid salt during treatment with China root, or to partake only of small quantities of rock salt. The chapter ends with Bhāvamiśra promising a complete and speedy cure through the mentioned remedies.

\section{Categories of disease: phirangaroga and syphilis}

From the summary of the chapter above, it should be clear that its contents cannot be understood in isolation, but as part of the larger context of the treatise. The fundamental principles of Ayurveda, its particular understanding of the body, methodology of diagnosis and treatment, etc., implicitly form the basis of any disease categorization and the treatments prescribed. Each chapter of the Bhāvaprakāśa is linked at various points with other parts of the treatise. In the chapter on phirangaroga, there are a number of explicit connections to other sections in the work (and to a wider ayurvedic knowledge), such as the reference

16 See Dutt 1877: 21 on the procedure of fumigation in skin diseases.

17 See Jolly 1994 [1951]: 34 on the difference between dhūma/dhūmapāna and dhūpana.

18 See Dutt 1877: 37 on pitapușpabalā as Sida cordifolia L. 
to visphoța to describe the symptoms of external phiranga, or to āmavāta for those of internal phiranga, as well as the prescription to treat the boil of external phiranga like an ulcer (vrana) after it has burst. There are also other sections in the Bhāvaprakāsa that mention syphilis and treatments against it. For example, a chapter in the pūrvakhaṇda (the first part of the Bhāvaprakāśa) on the processing of mercury contains a detailed description of how to produce rasakarpūra. ${ }^{19}$ The passage gives an alternative recipe against phiranga, in which rasakarpūra is mixed with cloves, sandalwood, saffron and musk. In the glossary (nighantu) section of the purrvakhanda, China root is discussed under its alternative name dvipāntaravaca ("mallow from another country"). Here, China root is prescribed for a range of complaints. It is defined as an effective medicine against any disease caused by the humour "wind" ( $v \bar{a} t a)$, epilepsy, insanity and bodyaches, as well as phiranga. ${ }^{20}$ However, the treatise does not necessarily furnish one with all the knowledge needed to make sense of each section of it. Much is left unexpressed and remains the domain of the expert knowledge of teachers or the individual experience of a physician. Note, for example, that while Bhāvamiśra describes seven different cures, he does not indicate in what relation the cures stand to each other, i.e., are they all to be used, or just one? Should one remedy be favoured over the other? Should they be used at different times? What are the paradigms of choice?

Principles that are relevant to knowing which medical compound to use may be found in the glossary section in which plant or other materials are defined as having certain properties that make them suitable or unsuitable for persons with particular bodily or mental constitutions (prakrti). This might help to decide which medicines to favour and which ones not to use for a particular patient. However, such principles can not tell us whether the multiple medicines might be used at different times or for the different stages of the disease. Bhāvamiśra does not overtly set the cures into relation with his proposed division of the disease into internal, external, internal/external and complications, raising the question of the point of discussing this division in the first place. However, one of the remedies is described as targeting particular symptoms: the third mercurial cure heals ulcers. This points to the possibility that the various cures could be used for the different stages of syphilis and their symptoms. The ayurvedic physician Uday Chand Dutt, who was writing in the late nineteenth century in Bengal, stated that the seven grain-of-rice pills were used in primary syphilis. ${ }^{21} \mathrm{He}$ also noted that the

19 See pūrvakhaṇda, dhātvādiśodhanamāraṇavidhiprakaraṇa, 181-189.

20 Bhāvaprakāśa pūrvakhaṇḍa haritakyādivarga 107-108.

21 Dutt 1877: 36-37. 
alternative recipe with rasakarpūra (with cloves, saffron, sandal and musk) was used in secondary syphilis. And Thomas Wise, who wrote in the first half of the nineteenth century, mentioned that China root was to be used after completing mercurial therapy. ${ }^{22}$ The problem is that Dutt (and also Wise) wrote some 300 years after Bhāvamiśra and it is difficult to know how closely their commentaries of Bhāvamiśra's text represent the latter's intention. It is possible that Dutt's explanation of the more specific use of syphilitic medicines is the result of a lineage of knowledge transfer from teacher to pupil that goes back to Bhāvamiśra's times and faithfully reflects Bhāvamiśra's original method of treatment. However, it is also possible that Bhāvamiśra intended no such division in the choice of medicines and that Dutt simply reinterpreted Bhāvamiśra's text based on a modern understanding of the disease. After all, Dutt notably did not make use of Bhāvamiśra's categorization of internal or external phiranga, but drew on the contemporary categories of primary, secondary and tertiary stages of syphilis.

The division into three stages was first proposed by Philip Ricord in the middle of the nineteenth century, and was the standard theory in modern medicine at the time Dutt was writing. ${ }^{23}$ Today, syphilis is divided in four stages: primary, secondary, latent and tertiary and is also understood to occur as a congenital disorder. ${ }^{24}$

Bhāvamiśra's division of internal, external and internal/external syphilis does not quite match descriptions of the symptoms of the three stages of syphilis (following the nineteenth-century understanding of syphilitic presentation). However, the ulcer of external phiranga may correspond to the chancre of primary syphilis, and several of the symptoms of internal phiranga (pain, loss of taste, lassitude, fever, and a swelling of the limbs) are symptoms of both primary and secondary syphilis. Some of the symptoms that Bhāvamiśra describes as the complications of phiranga, decay of the nose, bone atrophy and bone curvature, are now considered symptoms of congenital syphilis, but were described as general symptoms of syphilis in European sources in the sixteenth century. ${ }^{25}$ Thomas Wise, presumably interpreting the reference to visphoța as denoting a rash rather than a single boil, thought that Bhāvamiśra only described the symptoms of secondary syphilis. Wise included "affections of

22 Wise 1845: 378

23 Ricord's theory was published in notes in the third edition of John Hunter's A treatise on the venereal disease (1853).

24 See Marr 2007: 302-309 for a detailed description of the stages of syphilis and treatment.

25 See Pusey 1933: 34-41 on symptoms ascribed to syphilis in the sixteenth century. 
the bones, particularly those of the nose and palate" among the symptoms of secondary syphilis. ${ }^{26}$

\section{Ancient or new? Mercury as an antisyphilitic}

As we have seen, Bhāvamiśra's main therapies against syphilis consist in the administration of mercury, using it both internally and externally. Five out of seven of the treatments he describes involve the use of mercury, breaking his general pattern of favouring non-mercurial medicines over mercurial ones. This is not a minor difference: One must consider that out of seventy-one chapters of the therapy section, only fifteen give recipes containing mercury at all, usually placing one recipe for a medicine containing mercury or cinnabar at the end of a list of several herbal or mineral medicines. It should be emphasized that in no other chapter in the Bhāvaprakāśa do we encounter more mercurial remedies than non-mercurial ones. Furthermore, a closer look at the treatments in question reveals the recipes and the methods of their application to be highly unusual, both when compared with mercurial treatments in the Bhāvaprakāśa and with mercury therapies in other ayurvedic works. In the following, I will examine whether Bhāvamiśra's seemingly unorthodox choice of therapies reflects an outside, possibly European, influence or whether the remedies can be understood as derivations of older ayurvedic practices.

\subsection{Mercury in Indian medicine}

The use of mercury in medicine has a long tradition in India, with first (albeit contested) references to mercury appearing in the oldest of the classical Sanskrit medical texts known to us, the Carakasaṃhitā and the Suśrutasaminitā (c. first and third century CE, respectively). ${ }^{27}$

There is more certainty about the use of mercurial recipes in later works, notably in the Aștānngahṛdayasaṃitā and the Aștāngasamgraha, both c. seventh century CE. In these works we find various recipes for mercury treatments, both for topical and internal use. ${ }^{28}$ The Jain medical treatise Kalyānakāāraka (c. ninth

26 See Wise 1845: 377-378.

27 See Wujastyk 2013 for details on the possible occurrence of mercury in the Carakasamhitā and the Suśrutasaṃitā.

28 See Aṣtāñgahṛdayasaṃhitā Uttarasthāna.13.36 and Aṣṭāngasaṃraha Uttarasthāna.49.392 for a prescription of a medicinal paste for the treatment of the eye disease timira, 
century CE) by Ugrāditya is the earliest medical text to describe procedures for purifying (śodhana) and calcining mercury (märana, i.e., the calcination of mercury which makes it fit for pharmaceutical application). ${ }^{29}$ If its dating to the ninth century is correct, its descriptions of mercury processing are among the earliest in Sanskrit literature available to us at present.

Further works with some mercurial recipes include the Siddhayoga ${ }^{30}$ by Vrnda (ninth or tenth century), which prescribes an ointment against lice that contains mercury and the Cakradatta or Cikitsāsaṃgraha by Cakrapānidatta (eleventh century), which gives about nine recipes for mercurial medicines, all for internal use. The Cakradatta also describes simple procedures for purifying mercury which involve macerating mercury with the juice of a number of plants in one case, and rubbing it with copper and steam heating it in sour gruel in another case. ${ }^{31}$ Vangasena, who wrote the Cikitsāsārasamgraha in around the eleventh or twelfth century, presents quite a few recipes with mercury as an ingredient. ${ }^{32}$ He mentions mercury together with the technical terms vimürchita (solidified), mūrchana (solidifying), and śuddha (purified). ${ }^{33}$ And in a recipe for tāmrarasāyana (a tonic based on copper), Vangasena describes how mercury is washed with a decoction of the three pungent substances (black pepper, long pepper and dried ginger) and sublimated and then rubbed with sulphur for three days. He refers to the resulting mercurial product as mrtasūtaka, i.e. "killed mercury". 34

In the thirteenth century, the Sārngadharasaṃitā presents an elaborately formulated system of processing and using mercury. Its long chapter on mercury contains one quite complicated recipe for the purification of mercury (rasaśodhana), one recipe for purifying sulphur (gandhakaśodhana), two recipes for extracting mercury from cinnabar (daradaśodhana), four recipes for giving mercury a "mouth" to "devour" other metals, i.e., to absorb them, four recipes for the "killing", i.e., making into ash of mercury, and nearly fifty recipes for

Aṣțāngahṛdayasaṃhitā Uttarasthāna.32.31 for a recipe for a topical cream against freckles, and Aș̣̄āngahṛdayasaṃhitā Uttarasthāna.39.161 for a rejuvenatory tonic, the first ayurvedic recipe for the internal use of mercury. The edition of the Aștānngasaṃgraha by Srikantha Murthy (1995/ 1997) was used for this article.

29 See Meulenbeld 1999-2002: IIA, 152 on mercury in the Kalyāṇakāraka.

30 See Meulenbeld 1999-2002: IIA, 80 on mercury in the Siddhayoga.

31 See Cakradatta, chapter on amlapitta, 35 (rasaśuddhi) and chapter on rasāyana, 133. Also see Meulenbeld 1999-2002: IIA, 88 on mercury compounds in the Cikitsāsamgraha. The edition of the Cikitsāsaṃraha by Sharma (1994) was used for this article.

32 See Meulenbeld 1999-2002: IIB, 250 for a list of occurrences of formulations containing mercury.

33 See Cikitsāsārasaṃgraha rasāyanādhikāra 264, 287, and 461, respectively. The edition of the Cikitsāsārasaṃgraha (Vañgasenasaṃhitā) by Rāya/Rāya (1983) was used for this article.

34 Cikitsāsārasaṃgraha rasāyanādhikāra 75-76. 
medicines prepared from the above products. Most ayurvedic treatises written after the Śāngadharasaṃhitā incorporate sections on the processing of mercury or prescribe recipes which contain processed mercurial products.

\subsection{Mercury as an antisyphilitic in Indian medicine}

Phirañgaroga was not known to the author of the Śārngadharasaṃhitā, and none of the five mercurial recipes or treatment methods that Bhāvamiśra prescribes against phirangaroga are found in the earlier work. As a reminder: Bhāvamiśra's main recipe describes the ingestion of rasakarpūra (calomel or corrosive sublimate), about $500 \mathrm{mg}$ of which are encased in wheat flour and made into a pill, which is then covered in ground cloves and swallowed whole with some water. The second recipe describes the making of saptaśălivațika (seven grain-of-rice pills). Here, mercury is mixed with catechu, pellitory root and honey, and the patient takes a pill a day for seven days. In the third mercurial cure for ingestion a paste of mercury, sulphur and catechu is made to which a number of herbs, honey and ghee are added. In the fourth mercurial cure, mercury is mixed with sulphur and rice and the mixture is formed into seven pills. These are used for fumigation, one a day for seven days. The last mercurial recipe prescribes rubbing mercury and the juice of the leaves of yellow-flowering country mallow into one's hands until they are absorbed by the skin. The hands are then heated and made to sweat.

In the Śārngadharasaṃhitā, mercury is ingested mixed with honey or ghee, as a beverage, or in the form of pills (but not made from wheat and clove powder, or catechu, pellitory and honey). It is also applied as an eye ointment, smeared into the nose, rubbed into a small incision in the skin or used topically on areas of the skin affected by skin disease. ${ }^{35}$ Sarngadhara does not describe rubbing mercury into the hands and then heating the hands, or preparing mercury pills for fumigation. Rasakarpūra is also not mentioned, though Sarnigadhara suggests four different methods of producing ash of mercury. ${ }^{36}$ These do not correlate with Bhāvamiśra's instructions for making rasakarpūra: His recipe specifies that purified mercury should be mixed with equal parts of red ochre, brick dust, chalk, alum, rock salt, earth from an ant-hill, sodium

35 Eye ointment: Sārngadharasaṃhitā 2.12.135, smeared into the nose: Sārngadharasaṃhitā 2.12.136, rubbed into a small incision in the skin: Sāangadharasaṃhitā 2.12.121-126, used topically on areas of the skin affected by skin disease: Sāangadharasaṃhitā 2.12.190-193. The edition of the Sārngadharasaṃhitā by Srikantha Murthy (1984) was used for this article.

36 See Śārngadharasaṃhitā 2.12. 29-34, 35-38, 38-40 and 41-42. 
sulphate, and red earth (usually used for colouring pots). ${ }^{37}$ The mixture is strained through cloth and placed in an earthen pot, which is covered with another pot mouth to mouth. The pots are luted together with clay and cloth and then placed on a fire and heated for four days. After they are opened, the white camphor-like deposit in the upper pot is collected for use. ${ }^{38}$ Incidentally, this description of its production method and the recipe for a rasakarpurra pill in the phirangaroga chapter are the only instances in which rasakarpūra is mentioned in the Bhāvaprakāsa.

If we accept the notion that alchemical and medical works represent two distinct, though overlapping traditions, Bhāvamiśra's recipe for rasakarpūra is either the earliest or among the earliest in Sanskrit medical literature. However, a recipe for making calomel (no Sanskrit name is given for the product) already occurs in the Rasārnava, an important alchemical treatise dated to about the tenth or eleventh century. ${ }^{39}$ The alchemical treatise Rasendrasārasamgraha by Gopālakṛṣnā (c. late fifteenth/sixteenth century CE?) has a recipe for obtaining white ash (śvetabhāsman) of mercury. ${ }^{40}$ Its production method differs in that the ingredients (mercury, salt and the juice of Euphorbia neriifolia L.) are placed in an iron bottle for heating. ${ }^{41}$

A further alchemical work, the Rasendracintāmaṇi (thirteenth/fourteenth century) gives another detailed recipe, which contains several of the same ingredients as Bhāvamiśra's, namely brick-dust, alum and salt, and it calls the product karpūra, defining it as a remedy against all diseases (sarvarogaharī). ${ }^{42}$ Bhāvamiśra quotes from the Rasendracintāmaṇi a number of times, so it is quite

37 See Bhāvaprakāśa pūrvakhaṇḍa dhātvādiśodhanamāranavidhiprakaraṇa 182-190.

38 See Dutt 1877: 29.

39 The recipe is found in Rasārnava 11.24. according to Ray 1903: 250: "Green-vitriol, alum, salt, borax, mixed with the aforesaid vegetable drugs, (vide original text) kill mercury in an instant (in the shape of calomel)."

40 This recipe is found in 1.73-75 according to Meulenbeld 1999-2002: IIA, 730, who also notes that this work might be rather later than the estimated late fifteenth or sixteenth century.

41 "Rub mercury repeatedly with pāmssu salt and the juice of Euphorbia neriifolia; place the mixture inside an iron bottle, the mouth of which is closed with a piece of chalk. The bottle is embedded in a mass of salt and then fire is urged for an entire day. The white deposit in the neck of the bottle is to be collected." See Ray 1903: 252.

42 "I am now going to explain the process of preparing rasakarpura, which is a remedy for all diseases: take a strong earthen pot and fill one-fourth of it with common salt and place over it a mixture of brick-dust, alum and rock-salt. Rub mercury with the juice of Indian aloe and an equal weight of the above mixture into a paste; deposit it in the earthen pot and cover it with the same ingredients. The pot is to be firmly closed with a well-fitting lid. Now apply heat for three days together." See Ray 1903: 251. The dating of this work to the thirteenth or fourteenth century follows Ray 1903: 251. According to Meulenbeld 1999-2002: IIA, 705, the 
possible that his recipe for making rasakarpūra is derived from this work. ${ }^{43}$ Ray pointed out that both the recipe of Rasendracintāmaṇi and of the Bhāvaprakāśa seem to have an analogue in a Chinese method for preparing calomel, in which alum and salt were used. ${ }^{44}$ According to Meulenbeld, rasakarpūra is also mentioned in Nīlakaṇtha's Basavarājīya. ${ }^{45}$ This medical work might be a little earlier than the Bhāvaprakāśa, but its dating is uncertain. ${ }^{46}$ Another, broadly contemporaneous work to mention rasakarpūra is the alchemical treatise Rasamañjarī by Sālinātha. The earliest manuscript of this text was completed in 1546/47 CE, which means that the work is earlier than the middle of the sixteenth century, possibly as early as the last quarter of the fifteenth century. ${ }^{47}$ We also find rasakarpūra mentioned in Harṣakīrti’s Yogacintāmaṇi, a medical work that was probably written some decades after the Bhāvaprakāśa. Harșakīrti prescribed rasakarpūra against āmavāta, the symptoms of which Bhāvamiśra pronounced similar to those of internal phiranga.

In short, rasakarpūra is not an ancient mercurial product as was implied by Bhāvamiśra's remark in madhyakhanda 59.10 ("The ancient physicians said that the mercury known as "camphor" truly destroys the disease known as phiranga."), but was probably first used in India around the tenth or eleventh century (though it was not yet called rasakarpūra at that time) and received its name in the late fifteenth or early sixteenth century. One might argue that while the older recipes might have produced the same or a very similar product, the authors of these recipes may not have understood this product to be the same thing as the product of the others' recipes. However, it seems likely that, once they used the name rasakarpurra, they did think this was the same substance, even if the variations in ingredients and production methods might in fact have led to different products (with varying parts of calomel and parts of corrosive

Rasendracintāmani dates to between the middle of the fifteenth century and the second half of the sixteenth century.

43 Meulenbeld 1999-2002: IIA, 241 lists several passages in the Bhāvaprakāśa that mention the Rasendracintāmaṇi as their source.

44 Ray 1903: 254-256.

45 Meulenbeld 1999-2002: IIA, 461.

46 Meulenbeld 1999-2002: IIA, 461 argues that "the developed state of nādīparīkșā and rasaśāstra [i.e., pulse examination and alchemy], (...) indicate that it cannot be earlier than the fourteenth century. The prescription of rasakarpūra, although not yet against phirangaroga, points to the sixteenth century as the period of its composition. This is confirmed by the presence of China root in the prescriptions against venereal diseases." Unfortunately, Meulenbeld does not provide a reference for the location of rasakarpūra in the Basavarājīya. 47 Meulenbeld 1999-2002: IIA, 638. 
sublimate, for example). ${ }^{48}$ In any case, it seems safe to state that while rasakarpūra was a relatively late addition to the ayurvedic pharmacopoeia, its use preceded the arrival of the Portuguese in India. But can we perhaps connect the specific application of rasakarpūra against syphilis to the Portuguese, or to other Europeans who were present on the Indian subcontinent in the early to mid-sixteenth century? And what about Bhāvamiśra’s other prescriptions, i.e., fumigation with mercury, or rubbing mercury into one's hands?

\subsection{Similarities and differences in European and Indian anti- syphilitic mercury therapies}

In the first half of the sixteenth century in Europe, no single universally accepted treatment existed for treating syphilis. Mercurial treatments against syphilis consisted of three main methods: Smearing mercurial salves onto the patient's body, washing the body in baths with added sublimated mercury (i.e. corrosive sublimate), or fumigating the patient's body. ${ }^{49}$ In severe cases (i.e., when the former treatments showed no result), mercury fumes were inhaled directly. However, mercury preparations were also ingested from quite early on in the sixteenth century, the perhaps most famous preparation for internal use being Paracelsus' Turpethum minerale. ${ }^{50}$ Mercurial salves, such as the famous unguentum saracenicum, had been used in Europe against skin diseases since the late Middle Ages. While the specific recipe for this ointment does not correlate with any known recipe for ointments in Arabic medicine, as Bachour points out in this volume, the topical use of mercury against skin disease is well documented in Arabic medicine and is likely to have been the basis for the

48 See Ray 1903: 250-261, esp. 260-261 for a summary of a series of experiments following the recipes laid out in the Bhāvaprakāśa, Rasendracintāmaṇi, etc. Ray concluded that the Bhāvaprakāśa's recipe led to the production of a mixture of calomel and corrosive sublimate, due to the brick-dust. An alternative recipe without brick-dust produced pure calomel.

49 See Lesky 1959: 3174 and 3179-3180 on the use of mercury ointments in medieval Europe and on fumigation therapy and on baths with mercury salts, respectively. Also see Girtanner 1797: 303 for a reference to the earliest medical writers to endorse fumigation with mercury: Cataneus (1505), Bologninus (1507), Joh. Benedictus (1508) and Johann de Vigo (1513).

50 According to Girtanner (1797: 334), Johann de Vigo, personal physician to Pope Julius II, was among the first to prescribe pills of red precipitate of mercury for internal use. However, Girtanner's assertion cannot be confirmed. Rather, it seems that this preparation was only used topically by de Vigo to treat venereal ulcers. I would like to thank Dr. Natalia Bachour for pointing this out to me. 
European use of mercury ointments ${ }^{51}$ : For example, the famous eleventh-century Persian physician and philosopher Ibn Sīnā (Avicenna), whose Canon of medicine was hugely influential in European scholarly medicine, proposed the topical use of mercury against various skin diseases, though he warned against the internal use of mercury.

The toxicity of mercury was known, if not clearly understood, and physicians were very concerned with harnessing what they presumed to be the curative powers of mercury while keeping the side effects in check. This problem was tackled in three ways. First, by reducing the actual amount of mercury in mercurial remedies, trying to arrive at an amount that was both safe and effective. Second, by adopting methods developed in Arabic medicine of "extinguishing" (extinctio) or "killing" (mortificatio) mercury by mixing it with various substances (for example, with oil, lard, vinegar, or even saliva). Third, by adding further substances, such as lead, sulphur, arsenic, myrrh, frankincense and other herbal or mineral substances to the mix. These were meant to counteract or balance the characteristics of mercury which were seen as the root cause of its negative effects.

These negative effects could be dramatic, easily equalling the ravages of syphilis. The symptoms of intoxication included ulcerations of the jaws, loosening of the teeth, swelling of the tongue, lips and palate, salivation, and fetid breath. The overuse of mercury and particularly the inhalation of mercury fumes could (and apparently often did) kill the patient. So painful and difficult to bear were these mercury therapies that patients and physicians alike were desperate to find other cures. This partly explains the popularity of alternative remedies, such as the cure with guaiacum, or with China root. ${ }^{52}$

To return to the question whether we can relate Bhāvamiśra's depiction of antisyphilitic (or anti-phiranga) treatment with mercury to European methods of mercurial therapy, we can broadly point to some major differences. For example, Bhāvamiśra does not describe the making of a mercurial ointment for topical use. The one example of a topical use of mercury use is the recipe in which mercury is rubbed with the juice of the leaves of yellow-flowering country mallow into the patient's hands until they are absorbed by the skin. While one

51 On the problem of defining medicine in the medieval Islamic world as "Arabic", "Persian", "Islamic", "Greco-Arabic”, etc., see Pormann/Savage-Smith 2007, especially the chapter "The emergence of Islamic medicine”. For simplicity's sake, I adopt “Arabic medicine” here, keeping in mind the complexity of the situation of medical writing in the medieval Islamic world, where medical writers could hail from different regions, write in Arabic or Persian, and belong to different religious (also non-Islamic) groups, but would still be considered part of an intellectual continuum.

52 On the history of the use of China root, see Winterbottom 2014 and Wujastyk in preparation. 
might argue that a mix of mercury with the plant juice constitutes a kind of ointment, this is a very simple prescription when compared to the multicomponent ointments used in European medicine. Then, the topical use is restricted to the hands, the rest of the body is not anointed. There is at least one example of a European prescription to anoint the hands: The thirteenthcentury Byzantine physician Nicholas Myrepsos (or Nicolaus Myrepsus) seems to have prescribed rubbing a salve containing lead and mercury that had been warmed on a fire onto the hands and feet in his Dynameron (a large and very important compilation of Byzantine pharmaceutical recipes). ${ }^{53}$ However, this prescription predated the occurence of syphilis in Europe by more than two centuries and does not seem to have influenced antisyphilitic treatment methodology.

An important similarity between the Indian and European methods lies in the use of heat to aid the absorption of the mercury into the skin, though no special apparatus seems to have been used in the Indian case. Heating parts or, more typically, all of the body and inducing sweating is very much part of classical ayurvedic treatment. ${ }^{54}$ However, heating one particular part of the body (for example, by using hot poultices) is usually meant to tackle a problem in that area. It is difficult to explain the hands as the locus of treatment, both for the absorption of the medicine and for the expulsion of matter (sweat) from the body, and I do not know of a corresponding treatment either with or without mercury in the ayurvedic works. In sum, this is a curious remedy that can neither be clearly identified as relating to European methods of treatment nor fully explained as a derivation from ayurvedic standard treatments.

By contrast, fumigation (with other medicinal substances) as a therapeutic method is already recorded in the earliest ayurvedic works, so that fumigation with mercury could be seen as a simple derivation from an older idea. ${ }^{55}$ Bhāvamiśra's description leaves doubt as to whether the body should be fumigated or whether the fumes of the mercury pills should be inhaled. Either possibility has precedents in ayurvedic medicine (albeit not with mercury), and also occurs in European medicine. A connecting point between Bhāvamiśra's fumigation therapy and European methods lies in the mercurial substance used for producing the fumes. In Europe, this was typically cinnabar. Bhāvamiśra's recipe prescribes that liquid mercury is mixed with sulphur and

53 See Almkvist 1928: 181.

54 On ayurvedic sweating therapies, see Jolly 1994 [1951]: 34.

55 See Jolly 1994 [1951] 34 on dhūma and dhümapāna (fumigations in the nose or mouth) and dhūpana (the local application of smoke through a pipe in ulcers and skin diseases). Also see Dutt 1877: 21 on the procedure of fumigation in skin diseases. 
rice into a paste called kajjali, black sulfide of mercury (HgS), i.e., black cinnabar. Both cinnabar (Sanskrit: darada, hingula) and black sulfide of mercury feature largely in ayurvedic mercurial remedies. For example, most of the recipes in the thirteenth-century Śārngadharasaṃhitā for mercurial medicines are based on a mixture of mercury and sulphur. ${ }^{56}$ However, to my knowledge, there is no ayurvedic precedent for using mercury (with or without sulphur) for making pills for fumigation, and this is also the only instance in which mercury is used as a fumigant in any of Bhāvamiśra's formulations. ${ }^{57}$

For this reason, the possibility that fumigation with mercury as an antisyphilitic therapy was introduced to India by Europeans - for whom fumigation with mercury was, after all, a very standard therapy - cannot be discounted, though one would also need to consider whether it might have been adopted from Chinese or Persian medicine or already occurred in early Indian alchemical works. As Johannes Thomann shows in this volume, fumigation with mercury is described in one of the early Persian works to deal with syphilis, the Ğāmi alfawā ("Collection of notices") of Yūsufî, which was written in 1511. Natalia Bachour points out that the first European physicians to prescribe fumigation therapy for syphilis were all Italians. Therefore, Bachour suggests that "fumigation therapy might have been introduced into the Ottoman empire from Persia and after that, as a consequence of flourishing relations with Italy, into Europe, where it was further refined using a barrel-like appliance. ${ }^{58}$ However, the first Persian monograph on syphilis, the Risāla-i ātašak ("Epistle of the little fire"), written by Imād ad-Dīn Šīrāzì in 1569 CE, does not include prescriptions for fumigation with mercury. Nevertheless, it is described as a standard procedure

56 See chapter 12 of the second section of the Śārngadharasaṃitā.

57 It is possible, however, that mercury was described as a fumigant in iatrochemical sections of contemporary or earlier alchemical works, which I have not consulted. Ainslie (1826: vol. 2., 354), paraphrasing a Tamil medical work he called Poorna Soostrum, described the use of a cinnabar product called shadilingum as a fumigant: "Eight pagodas weight of yercum vayr puttay (the bark of the root of the asclepias gigantea), four pagodas weight of shadilingum, and one pagoda weight of pepper, are all to be ground together, with the juice of the leaves of the paratie cheddie (gossypium herbaceum), and when well ribbed, to be formed into twelve cakes and dried. The fumes of one of these cakes, while burning, to be inhaled daily, through a smoking pipe, either all at once, or at two different periods in the twenty-four hours. Fumigation of this sort may be continued for five or six days, according to circumstances; and is efficacious in the two disorders called by the Tamools kannosie and kanna poottoo (cancerous affections), in venereal ulcers of the throat and nose, and in a disease attended with a singular pricking pain in the scull.” Tamil medical works are thought to be closely connected to Indian alchemical traditions, and therefore the occurence of mercury as a fumigant in this particular work could go back to an original prescription in an older alchemical work.

58 See Bachour in this volume. 
in the literature of Unani (or Graeco-Islamic) medicine as C. Preckel shows in this volume.

There is a case to be made that the idea of fumigation with mercury ultimately goes back to Chinese medicine: The sixteenth-century Bencao Gangmu mentions the use of mercury as a fumigant and since its author Li Shizhen often relied on information from older works, it seems likely that there was a Chinese precedent of fumigation with mercury, if perhaps not against syphilis. ${ }^{59}$ Li Shizhen describes using mercury for fumigation by preparing small sticks of mixtures of mercury (most often in the form of cinnabar) and other substances (minerals, herbs and, in one case, a snake). In most recipes, the fumes of these sticks would be applied to the affected body parts. One prescription, which describes burning a mixture of cinnabar, realgar and soot inside a quilt that covers the patient is perhaps similar to the European sweating bed. ${ }^{60}$ However, one should note that Li Shizhen's fumigation stick recipes are much more complex than Bhāvamiśra's fumigation pills of mercury sulphide and rice, usually adding several ingredients.

As for the internal use of mercury, it is difficult to pinpoint the exact moment a mercury preparation was consumed for medical purposes in Europe. Up to, and indeed during the sixteenth century, most university-trained physicians seem to have generally been biased against the internal use of mercury, but some informal medical practices of consuming mercury preparations seem to have existed. The sixteenth-century Renaissance physician Paracelsus became famous for advocating the internal use of mercury in Europe. Paracelsus was critical of the Arabic-style multi-component mercurial salves and instead suggested making mercury the main component of treatment and using it internally. ${ }^{61}$ His medicine against syphilis, called Turpethum minerale, the exact recipe of which is not known, was probably some form of mercury sulphide.

Corrosive sublimate had been known in Europe for much longer. Some procedures for producing it are described in Gerard of Cremona's De Aluminibus et Salibus (twelfth century CE), an influential work believed to have been translated from an Arabic version of a Persian alchemical work by Muhammad ibn Zakariyā Rāzī (Rhazes), probably either his Al-asrar ("The

59 See the section on drugs for treating syphilitic skin lesions in the chapter "On medicines for the treatment of the hundred diseases" (Baibing zhuzhi yao), Shizhen 2003: I, 676-679, esp. 678-679 "The Category of Metals and Stones". My sincere thanks to Dr Daniel Trambaiolo for clarifying the title of the chapter and its position in the treatise.

60 For details of these recipes, see Shizhen 2003: I, 678-679.

61 See Lesky 1959: 3182. 
Secret") or his later work, Sirr Al-asrar ("Secret of Secrets"). ${ }^{62}$ And in the thirteenth century, Raymund Lull (Ramon Llull) described how to make a medicine from it that was to be taken internally. ${ }^{63}$

Calomel, however, was only "discovered" in Europe in the early seventeenth century: Jean Béguin wrote about it in 1608, Oswald Croll in $1609 .{ }^{64}$ It appeared in John Woodall's Surgion's Mate of 1617, the latter "published chiefly for the benefit of young sea-surgions imployed in the East-India Companies affaires"65 and was recorded in the first London Pharmacopoeia in 1618.

The Indian recipes for rasakarpūra and its precursors, which seem to have produced a mixture of calomel and corrosive sublimate, therefore clearly predate the European recipes for calomel, though perhaps not as definitively for corrosive sublimate. Furthermore, calomel only really started being used internally in Europe in the eighteenth century, after the Dutch physician and botanist Herman Boerhaave (1668-1738) and the Scottish physician and chemist Andrew Plummer (1697-1756) advocated its internal use against syphilis. Boerhaave's pupil, the Dutch-Austrian physician Gerard van Swieten (1700-1772) is credited with popularizing calomel across Europe. ${ }^{66}$ Indeed, Mark Harrison argues that Europeans, and particularly the British were influenced by Indian medicine in their use of mercury, the latter developing a colonial medicine with theories and methods of treatment that were quite distinct from those of the medical establishment in Britain. Harrison describes how two surgeons of the East India Company, John Wilson and Gilbert Pasley, began to administer calomel pills to patients diagnosed as suffering from inflammatory diseases of the liver in the 1750 s. ${ }^{67}$ This was non-standard practice, as calomel was more or less exclusively used against venereal disease in Britain at that time, though Boerhaave had already endorsed the use of calomel against non-venereal complaints some decades earlier. Harrison suggests that the two surgeons probably "drew their inspiration from the bazaar located near the Madras hospital, in which Indian practitioners regularly sold mercurial remedies. (...) Both men had a contract to supply their hospital with bazaar medicines and would have been familiar with local practices; they would have regularly purchased mercury, which was

62 See Needham et al. 1997: 124, note a.

63 See Lesky 1959: 3183. On Raymond Lull's recipe for making white ash of mercury, see chapter three of his The Clavicle, Lull 1680.

64 See Lesky 1959: 3183.

65 This is a subheading on the title page of Woodall 1617.

66 On Boerhaave, Plummer and van Swieten as advocates of the internal use of calomel in medicine, see Lesky 1959: 3184.

67 See Harrison 2010: 146-147. 
already extensively used to treat venereal complaints."68 However, the degree to which Wilson and Pasley were in fact influenced by local practice - other than using local products - cannot be ascertained. The other ingredients of their calomel pills, gum arabic and ipecacuanha, were certainly not standard ingredients in ayurvedic medicine or Siddha (a South Indian medical tradition that is closely related to the classical Sanskrit medical tradition, see also the contribution by Brigitte Sébastia in this volume) - at least not ipecacuanha, a South American plant known in Europe since the seventeenth century. ${ }^{69}$

To conclude the list of differences between Bhāvamiśra's and European views on mercurial therapies, treatments with mercury were associated with severe side effects in Europe, developing sores and swelling in the mouth and throat being among them. Another symptom of mercury treatment noted in Europe, first as a desired effect of mercury treatment and later as a sign of overdosage, was extreme salivation. Surprisingly, salivation is not mentioned at all in the context of mercury treatment in the Bhāvaprakāśa. A contemporary alchemical and iatrochemical work, the Rasaratnasamuccaya, describes "udgāra" as a symptom of "mercury sickness" (Sanskrit: pāradavikāra). ${ }^{70}$ Udgāra can mean "spitting” and "salivation", but more commonly means "eructation". In the medical works, salivation as a symptom of mercury poisoning (interpreted as being caused by the intake of unpurified mercury) seems to have first been described in the Bhaișajyaratnāvalī (Chapter 97 pāradavikāracikitsāprakaraṇam 8). The word used here is lālāsrāva: the "morbid flow of saliva". This important medical work is usually dated to the eighteenth century. However, there is reason to date some parts of it to the nineteenth century, including the chapter on mercury poisoning. $^{71}$

As for swelling in the mouth, Bhāvamiśra does remark upon it, albeit only to claim that his medicine would not cause it (see madhyakhanda 59.11 and 30). This, however, implies that Bhāvamiśra was aware of the possibility of causing swelling in the mouth through mercury treatments. Strangely, he does not list this symptom as one of the problems associated with mercury therapy in the section dedicated to the dangers of mercurial treatments (pūrvakhanda dhātvādivarga 90-95), just as no mention of salivation is found there. In that section, Bhāvamiśra explains that mercury can have two kinds of faults, innate (naisargika) and acquired (upādhija) ones. The innate faults of mercury are

68 Harrison 2010: 147.

69 See Flückiger 1867: 230 on the history of the use of ipecacuanha.

70 See Rasaratnasamuccaya 11.132. On the treatise, see Meulenbeld 1999-2002: IIA, 666-674. 71 See Meulenbeld 1999-2002: IIA, 336 on the dating of this work. The Govindadāsa et al. 2006 edition of the Bhaișajyaratnāvalī was consulted for this article. 
defined as dirt (mala), poison (vișa), fire (vahni), heaviness (gurutva), and being unsteady (capala), the acquired faults as the admixture of tin (vanga/trapu) and lead (nāga). ${ }^{72}$ Each fault is associated with a particular problem: Dirt causes fainting, poison kills, fire causes a severe burning sensation, heaviness leads to exhaustion and unsteadiness to the loss of virility; tin produces skin disease (perhaps leprosy) and lead causes impotence. Bhāvamiśra (pūrvakhaṇḍa dhātvādivarga 100) concludes that

therefore, mercury must be purified before use. The faults of fire, poison and dirt are the most severe, and must be removed. Consuming mercury that has not been subjected to different processes will destroy the body or give rise to diseases like leprosy. ${ }^{73}$

It is important to understand that mercury used in any ayurvedic recipe should have been processed according to prescription, and it would have therefore been considered safe: According to the ayurvedic view, proper treatment with mercury should never have negative consequences. ${ }^{74}$

\section{Conclusion}

In conclusion, it is not quite possible to make out a definite connection between the Bhāvaprakāsa's prescriptions and standard early to mid-sixteenth century European methods of using mercury as an antisyphilitic. At the same time, one cannot entirely discount the possibility that Bhāvamiśra's mercury treatments were inspired by European methods of treating syphilis either. In the case of fumigation with mercury, it seems at least possible that this treatment was introduced to India by Europeans, though it may equally have been adopted from Persian medicine or indeed Chinese medicine (perhaps via Persian

72 One should note that neither tin or lead are considered to be a poisonous substance on their own, but are also listed as medicinal substances in Bhāvaprakāśa pūrvakhaṇda dhātvādivarga. 73 The methods Bhāvamiśra suggests for ridding the mercury of its faults are mixing it with various substances. This is called mardana (maceration) or mūrchana (thickening, solidifying) and both are understood to be methods of purification (śodhana). See Bhāvaprakāśa pūrvakhaṇda dhātvādiśodhanamāraṇavidhiprakaraṇa 157-160, and 165-166. Bhāvamiśra also describes various sublimation processes for purifying mercury, one set of which is called mārana ("killing"), in which mercury is reduced to ash. The method for producing rasakarpūra is included in this set of procedures, so that its production should be understood as part of the purification (or perfecting) process. See pūrvakhaṇda dhātvādiśodhanamāranavidhiprakaraṇa 161-199, and 182-190 on rasakarpūra specifically. On ayurvedic methods of purifying mercury, see Wujastyk 2013.

74 On the treatment of mercury poisoning in various alchemical and medical works, see Wujastyk 2013. 
medicine). And finally, one must also keep in mind that there were a great many methods in Europe of treating syphilis with mercury, and even more different recipes for mercurial medicines, many of which may never have been written down so that one cannot completely rule out a connection between Bhāvamiśra's other prescriptions and European methods.

A further examination of the links between the antisyphilitic therapies of Persian, Chinese and Indian medicine might not only shed light on the history of syphilis but might also lead to a deeper understanding of the historical connections and entanglements of Chinese, Persian and Indian medicine.

Acknowledgements: The author would like to thank the URPP Asia and Europe, University of Zurich, and the Fonds zur Förderung des akademischen Nachwuchses (FAN) of the University of Zurich for funding the research and the writing of this paper. The final version of this paper was made possible through funding under the ERC Starting Grant ERC-2014-StG - 639363 AYURYOG.

\section{Bibliography}

Ainslie, Whitelaw (1826): Materia Indica: or Some Account of Those Articles Which are Employed [by] the Hindoos and Other Eastern Nations in Their Medicine, Arts, and Agriculture. London: Longman.

Almkvist, Johan (1928): Syphilis-Therapie. Handbuch der Haut- und Geschlechtskrankheiten. Berlin: Springer.

Basavarāja (2005): Vaidyavaraśrībasavarājaviracitam basavarājīyam. Vrajajīvana āyurvijñāna granthamālā 35. Dillī: Caukhambā Saṃskṛta Pratișṭhāna.

Dole, Vilas A./Paranjpe, Prakash (2004): A Text Book of Rasashastra. The Chaukhamba Ayurvijnana Studies 56. Delhi: Chaukhamba Sanskrit Pratishthan.

Dutt, Uday Chand (1877): Materia Medica of the Hindus... with a Glossary of Indian Plants by George King and the Author. Calcutta: Thacker and Spink. Reprinted, Varanasi 1980.

Flückiger, Friedrich August (1867): Lehrbuch der Pharmakognosie des Pflanzenreiches: Naturgeschichte der wichtigeren Arzneistoffe vegetabilischen Ursprungs. Berlin: Rudolph Gaertner.

Girtanner, Christoph (1797): Abhandlung über die venerische Krankheit. Dritte, vermehrte und durchaus verbesserte Auflage. Göttingen: Johann Christian Dieterich.

Govindadāsa, Brahmaśańkara Miśra et al. (2006): Bhaișajyaratnāvalī of Shri Govinda Dasji. 2. vols. The Chaukhambha Sanskrit Bhawan series 67. Varanasi: Chaukhambha Sanskrit Bhawan.

Harrison, Mark (2010): Medicine in an Age of Empire and Commerce: Britain and Its Tropical Colonies, 1660-1830. Oxford: Oxford University Press.

Hellwig, Oliver (2010-2012): DCS - The Digital Corpus of Sanskrit. Heidelberg. Last consulted on 28 July, 2015. http://kjc-fs-cluster.kjc.uni-heidelberg.de/dcs.

Jolly, Julius (1994 [1951]): Indian Medicine, Translated from the German...by C.G. Kashikar. New Delhi: Munshiram Manoharlal, 3 edn. 
Lesky, Erna (1959): “Von Schmier- und Räucherkuren zur modernen Syphilistherapie”.

CIBA-Zeitschrift 96.8: 3174-3190.

Lull, Ramón (1680): “Clavicula, or, a Little Key, ... which is Also Called Apertorium (the opener), in Which All That Is Required in the Work of Alchymy is Plainly Declared". In: Aurifontina Chymica, etc. Edited by John Frederick Houpreght. London: William Cooper.

Marr, Lisa (2007): Sexually Transmitted Diseases. A Physician Tells You What You Need to Know. Baltimore, MD: John Hopkins University Press.

Meulenbeld, Gerrit Jan (1999-2002): A History of Indian Medical Literature, 5 vols. Groningen: E. Forsten.

Needham, Joseph et al. (1997): Chemistry and Chemical Technology, vol. 5.3 of Science and Civilisation in China, v.5: Chemistry and Chemical Technology. Spagyrical Discovery and Invention: Historical Survey, from Cinnabar Elixirs to Synthetic Insulin. Cambridge: Cambridge University Press.

da Orta, Garcia (1987[1913]): Colloquies on the Simple[s] and Drugs of India, Translated by Clements Markham. Delhi: Sri Satguru Publications.

Pormann, Peter E./Savage-Smith, Emilie (2007): Medieval Islamic Medicine. Edinburgh: Edinburgh University Press.

Pusey, W. Allen (1933): The History and Epidemiology of Syphilis. Springfield, Baltimore, MD: Charles C Thomas.

Ray, Praphulla Chandra (1903): A History of Hindu Chemistry from the Earliest Times to the Middle of the Sixteenth Century A.D. with Sanskrit Texts, Variants, Translation and Illustration. Vol. I. Calcutta: The Bengal Chemical and Pharmaceutical Works.

Rāya, Rāmak Kumāra/Rāya, Rājīva Kumāra (eds.) (1983): Vañgasenasaṃhitā (Cikitsāsāra saṃgraha). Vārāṇasī: Prācya Prakāśana.

Reddy, D.V.S. (1936): Antiquity of Syphilis (Venereal Diseases) in India. Bombay: Medical Digest. Reprint from the Indian Journal of Venereal Diseases, vol. 2, June 1936.

Sharma, Priya Vrat (ed.) (1994): Cakradatta (Text with English Translation: A Treatise on Principles and Practices of Ayurvedic Medicine). Varanasi, Delhi: Caukhambha Orientalia.

Sharma, Priya Vrat (1999-2001): Suśruta-Saṃhitā, with English Translation of Text and Dalhana's Commentary Alongwith (sic) Critical Notes, 3 vols. Varanasi: Chaukhambha Visvabharati.

Sharma, Priya Vrat (2003): Caraka-Saṃhitā: Agniveśa's Treatise Refined and Annotated by Caraka and Redacted by Dṛhhabala (Text with English Translation), 4 vols. Varanasi, Delhi: Chaukhambha Orientalia.

Shizhen, Li (2003): Compendium of Materia Medica (Bencao Gangmu). Translated and Annotated by Luo Xiwen. Beijing: Foreign Language Press.

Srikantha Murthy, K.R. (1984): Śārngadhar-saṃhitā (A Treatise on Āyurveda) by Śārngadhara, Translated into English. Varanasi, Delhi: Chaukhambha Orientalia.

Srikantha Murthy, K.R. (1991-1995): Vāgbhața's Aștāãnga Hṛdayam: Text, English Translation, Notes, Appendix, and Indices. 3 vols. Varanasi: Krishnadas Academy.

Srikantha Murthy, K.R. (1995-1997): Așțāñga Samgraha of Vāgbhața: Text, English Translation, Notes, Indices etc, 3 vols. Varanasi: Chaukhambha Orientalia.

Srikantha Murthy, K.R. (1998-2000): Bhāvaprakāśa of Bhāvamiśra (Text, English Translation, Notes, Appendices, and Index), 2 vols. Varanasi: Krishnadas Academy.

Varthema, Ludovico di (1863): The Travels of Ludovico di Varthema in Egypt, Syria, Arabia Deserta and Arabia Felix, in Persia, India, and Ethiopia, A.D. 1503 to 1508; Translated from the Original Italian Edition of 1510, with a Preface by John Winter Jones and Edited, with Notes and an Introduction by George Percy Badger. London: The Hakluyt Society. 
Winterbottom, Anna E. (2014): "Of the China Root: A Case Study of the Early Modern Circulation of Materia Medica”. Social History of Medicine 28.1: 22-44.

Wise, Thomas A. (1845): Commentary on the Hindu System of Medicine. Calcutta: Thacker. Woodall, John (1617): The Surgions Mate, or, A Treatise Discovering Faithfully and Plainely the Due Contents of the Surgions Chest, the Uses of the Instruments, the Vertues and Operations of the Medicines, the Cures of the Most Frequent Diseases at Sea. London: Edward Griffin for Laurence Lisle.

Wujastyk, Dagmar (2013): "Perfect Medicine. Mercury in Sanskrit Medical Literature”. Asian Medicine - Tradition and Modernity 8: 15-40.

Wujastyk, Dagmar (in preparation): Coping with change: Disjunctures, adaptations and continuities in $16^{\text {th }}$ - to $19^{\text {th }}$-century Ayurveda. Habilitation thesis.

Wujastyk, Dominik (2003): The Roots of Āyurveda: Selections from Sanskrit Medical Writings. London, New York, etc.: Penguin Group.

Yule, Henry/Burnell A.C. (2000 [1903]): Hobson-Jobson: A Glossary of Colloquial Anglo-Indian Words and Phrases.... New Delhi: Munshiram Manoharlal.

Zysk, Kenneth G. (2000): “Does Ancient Indian Medicine Have a Theory of Contagion?” In: Contagion: Perspectives from Pre-modern Societies. Edited by Lawrence I. Conrad and Dominik Wujastyk. Aldershot, Burlington USA, Singapore, Sydney: Ashgate, 79-95. 